Memoria de título de Periodista, Universidad de Chile

ENTRE EL RECLAMO Y EL SILENCIO, LO PÚBLICO Y LO PRIVADO.

ANÁlisis DEL VACIAMIENTO POLÍTICO EN EL ARTE CHILENO

CONTEMPORÁNEO

Francisca Babul

Año 2007

\title{
Ximena Póo
}

Lo político y sus bordes; el arte y sus límites sobre lo político. Eso es lo que Francisca Babul aborda, desde una perspectiva crítica, en su memoria de título "Entre el reclamo y el silencio, lo público y lo privado. Análisis del vaciamiento político en el arte chileno contemporáneo". Se trata de un texto clarificador, que logra construir un mapa del estado del arte en Chile desde 1960 en adelante, centrándose en la transición a la democracia, un largo periodo que va desde 1989 hasta 2007. Es notable cómo ella presenta un complejo escenario cultural al investigar en un campo en donde el discurso ideológico, en el marco de un contexto social y político trizado, es fundamental en la construcción del mismo campo.

La transición a la democracia está minada por transiciones internas, silencios y transgresiones de las que las artes visuales se han hecho cargo. El "vaciamiento político" que ella plantea se observa en el sentido de desplazamiento del discurso hacia centros de interés que plantean "lo político" desde ámbitos más bien relacionados con las historias mínimas y ya no con los grandes discursos que perneaban el campo en las décadas anteriores. Aquí se da cuenta de una fragmentación, de un tropiezo hacia el subjetivismo y el regreso del "yo" mientras se repliega el discurso social que deja su impresión en la tríada objeto-sujeto-contexto. ¿El arte debe cumplir con la promesa social? Esa es la pregunta que circula una y otra vez, interpelando a creadores y críticos entrevistados y citados: Guillermo Machuca, Lotty Rosenfeld, Camilo Yánez, Juan Pablo Langlois; Voluspa Jarpa, Gonzalo Díaz, Diamela Eltit y Mónica Bengoa son algunos de los nombres que destacan entre los cuales Babul buscó pistas sobre lo qué ha pasado en estos años en torno a la interrogante planteada y otra no menos disruptiva: ipor qué atrapan las narrativas del yo?

El mapa incluye fotografías de trabajos clave, donde todos, insiste 
Babul, "tienen una lectura política" con distinciones, ya que "en algunos casos este aspecto logra un nivel de visibilidad mayor, hecho que, indudablemente, se relaciona también con el público receptor de dichos trabajos y con las categorías que los espectadores utilicen a la hora de decodificar el lenguaje visual". A partir de ahí, el desafío se amplía y se traspasa a las precariedades teóricas para comprender los virajes incluidos en los discursos dominantes en los espacios biográficos de un campo incierto, un campo que es la mancha fragmentada que cubre los mundos y sus bordes que se van formando a pesar de todo y todos. 